\title{
PEMANFAATAN TEKNOLOGI INFORMASI UNTUK PENGEMBANGAN KEMAMPUAN BERHITUNG ANAK USIA DINI
}

\author{
Lulu Choirun Nisa, S.Si, M.Sc
}

Fakultas Tarbiyah IAIN Walisongo Semarang

\begin{abstract}
Abstrak
Beberapa tahun terkahir ini anak usia dini dituntut untuk menguasai kemampuan berhitung sebelum masuk SD/MI. Sementara menurut psikologi matematika, keterampilan berhitung dijinkan untuk dipelajarkan ke anak asalkan konsep dasar pendukungnya sudah dikuasai. Adapun konsep dasar pendukung dari keterampilan berhitung adalah kemampuan mengurutkan, membandingkan, mengumpulkan, konsep himpunan, korespondensi satu-satu, dan bilangan kardinal.

Sebagaimana yang disampaikan oleh Piaget bahwa anak usia dini masuk pada tahapan sensorimotor dan praoperasi dimana pada tahapan ini anak belum mampu menggunakan aturan yang jelas atau logis, maka pembelajaran konsep berhitung dan pendukungnya tidak dapat disampaikan secara formal. Oleh karena itu penggunaan media mutlak diperlukan.

Salah satu media yang dapat menjadi alternatif adalah media berbasis teknologi. Media ini mempunyai banyak kelebihan, antara lain kemudahan akses, tahan lama, mudah menyimpannya, serta dapat didesain secara fleksibel sesuai kebutuhan anak.Teknologi informasi juga sangat tepat untuk anak usia dini karena dapat orangtua/ pendidik dapat memasukkan unsur warna, musik, atau karikatur yang sesuai dengan kesukaan anak. Adapun untuk menunjang keterampilan berhitung, anak dapat dikenalkan dengan kalkulator, Microsoft PowerPoint, internet, atau mobile teknologi seperti handphone dan tablet.
\end{abstract}

Kata Kunci: anak usia dini, media pembelajaran, teknologi informasi 


\section{A. Pendahuluan}

Anak usia dini didefinisikan secara berbeda oleh berbagai lembaga. Departemen Pendidikan Nasional (sekarang Kementerian Pendidikan dan Kebudayaan) menyebutkan bahwa anak usia dini adalah anak yang berada dalam rentang usia 0-6 tahun (Depdiknas, 2003). Sedangkan menurut ensiklopedia elektronika Wikipedia, rentang usia yang termasuk dalam kategori usia dini adalah 0-8 tahun. Rentang 0-8 tahun ini sama dengan klasifikasi anak usia dini oleh NAEYC (National Association of Education for Young children), suatu asosiasi PAUD Amerika Serikat. UNESCO melalui International Standard Classification of Education (ISCED)nya menyebutkan jenjang Prasekolah atau level 0 , yang disebut juga sebagai pendidikan anak usia dini, adalah pendidikan bagi anak usia 3-5 tahun.

Meskipun mempunyai definisi yang berbeda, namun pentingnya pengembangan kemampuan anak pada usia dini disadari dan diakui oleh hampir seluruh negara. Di Indonesia, landasan hukum pelaksanaan pendidikan anak usia diniantara lain ada di dalam Amandemen UUD 1945 pasal 28 ayat $2^{1}$, UU Nomor 23 tahun 2002 pasal 9 ayat 1 tentang Perlindungan $\mathrm{Anak}^{2}$, UU Nomor 20 tahun 2003 tentang Sistem Pendidikan Nasional Bab 1 Pasal 1 butir 14, dan UU Nomor 20 tahun 2003 tentang Sistem Pendidikan Nasional pasal 28 tentang Pendidikan Anak Usia Dini. ${ }^{4}$

1 Amandemen UUD 1945 pasal 28 ayat 2: "Setiap anak berhak atas kelangsungan hidup, tumbuh dan berkembang serta berhak atas perlindungan dari kekerasan dan diskriminasi."

${ }^{2}$ UU No. 23 Tahun 2002 Pasal 9 Ayat 1 tentang Perlindungan Anak: "Setiap anak berhak memperoleh pendidikan dan pengajaran dalam rangka pengembangan pribadinya dan tingkat kecerdasarnya sesuai dengan minat dan bakatnya."

${ }^{3}$ UU No. 20 Tahun 2003 tentang Sistem Pendidikan Nasional Bab 1, Pasal 1, Butir 14: "Pendidikan Anak Usia Dini adalah suatu upaya pembinaan yang ditujukan kepada anak sejak lahir sampai dengan usia 6 tahun yang dilakukan melalui pemberian rangsangan pendidikan untuk membantu pertumbuhan dan perkembangan jasmani dan rohani agar anak memiliki kesiapan dalam memasuki pendidikan lebih lanjut."

${ }^{4}$ Pasal 28 tentang Pendidikan Anak Usia Dini: (1) Pendidikan anak usia dini diselenggarakan sebelum jenjang pendidikan dasar, (2) Pendidkan anak usia dini dapat diselenggarakan melalui jalur pendidkan formal, non formal, dan/atau informal, (3) Pen- 
Dari beberapa landasan hukum tersebut menunjukkan bahwa salah satu tujuan pelaksanaan pendidikan anak usia dini, baik yang dilaksanakan di dalam lembaga formal (TK), informal (KB) maupun non formal (keluarga dan lingkungan), adalah untuk mempersiapkan anak memasuki pendidikan jenjang berikutnya. Landasan hukum tersebut juga menyebutkan salah satu tugas utama dari pendidikan anak usia dini adalah memberikan rangsangan sehingga potensi yang telah ada secara alamiah dapat tumbuh dan berkembang secara optimal. Potensi yang telah dimiliki anak dapat berupa potensi fisik dan potensi psikis.Potensi fisik meliputi kekuatan, ketahanan, daya ledak, kecepatan, koordinasi, kelenturan, keseimbangan, ketepatan dan kelincahan; sedangkan potensi psikis meliputi berbagai aspek kecerdasan intelektual atau kognitif, emosional, mental, sosial, moral dan spiritual. ${ }^{5}$ Terkait dengan potensi kecerdasan kognitif, salah satu kemampuan yang perlu dipersiapkan untuk memasuki jenjang berikutnya (Sekolah dasar) adalah kemampuan berhitung.

Terlepas dari perdebatan perlu tidaknya pembelajaran berhitung pada anak usia dini, mempersiapkan anak untuk mampu menguasai konsep berhitung dengan baik sangat perlu dilakukan. Hal ini dikarenakan kecerdasan matematika merupakan kecerdasan tipe B, yang tidak diturunkan secara genetika namun diperoleh melalui asahan terhadap konsepkonsep pendukungnya. ${ }^{6}$ Bruner bahkan menyatakan bahwa materi apapun sebenarnya dapat diajarkan pada anak-anak, asalkan dengan metode yang tepat. ${ }^{7} \mathrm{Hal}$ ini menegaskan bahwa berhitung sebenarnya sah-sah saja dikenalkan pada anak usia dini jika dengan metode yang sesuai.

didikan anak usia dini jalur pendidikan formal: TK, RA, atau bentuk lain yang sederajat, (4) Pendidikan anak usia dini jalur pendidikan non formal: KB, TPA, atau bentuk lain yang sederajat, (5) Pendidikan usia dini jalur pendidikan informal: pendidikan keluarga atau pendidikan yang diselenggarakan oleh lingkungan, dan (6) Ketentuan mengenai pendidikan anak usia dini sebagaimana dimaksud dalam ayat (1), ayat (2), ayat (3), dan ayat (4) diatur lebih lanjut dengan peraturan pemerintah.

${ }^{5}$ Sujiono \& Sujiono, Menu Pembelajaran Anka Usia Dini, (Jakarta: Yayasan Citra Pendidikan Indonesia, 2005).

6 Skemp, R., The Psychology of Learning Mathematics, (England: Harmondsworth, Middlesex.Penguin Books Ltd., 1971).

7 NewFoundations, (2001), "Jerome Bruner's Educational Theory" , http:// newfoundations.com/gallery/bruner.html (diakses 1Juni 2008) 
Bermain sambil belajar merupakan esensi bermain yang menjiwai setiap kegiatan pembelajaran anak usia dini. ${ }^{8}$ Bagi anak, benda apa saja dapat dijadikan permainan. Dengan bermain, anak berinteraksi dengan objek dan secara sadar atau tidak sadar ia mempelajari atribut objek tersebut. Oleh karena itu, Piaget menyatakan pentingnya objek nyata untuk belajar pada anak usia dini. ${ }^{9}$ Anak mulai memperoleh informasi melalui interaksinya dengan objek dan kelak informasi ini akan disusun dalam struktur pengetahuannya.

Selain objek nyata, media lain yang dapat digunakan untuk mentransformasi pengetahuan atau kemampuan pada anak usia dini adalah melalui teknologi informasi. Dengan teknologi informasi, pembelajaran dapat didesain sesuai dengan tahapan perkembangan anak dan dengan tujuan yang spesifik. Selain itu, teknologi informasi sangat tepat untuk anak usia dini karena dapat memasukkan unsur warna, musik, atau karikatur yang sesuai dengan kesukaan anak. Sehingga diharapkan minat anak akan meningkat dan tidak bosan untuk mengulangi pembelajaran. Bagi pendidik atau orangtua sendiri, media teknologi informasi sangat menguntungkan karena dibandingkan dengan media fisik yang rentah rusak, media teknologi informasi lebih lekang oleh waktu dan mudah penyimpanannya.

Untuk pembelajaran berhitung, meskipun melalui media teknologi informasi anak tidak dapat melakukan manipulasi fisik yang juga penting untuk membangun pengetahuannya, aspek tersebut dapat diwakilkan melalui animasi atau permainan. Sehingga dengan desain yang tepat, perkembangan teknologi yang pesat dapat dimanfaatkan oleh pendidik (guru, orangtua atau pengasuh) untuk mempermudah menanamkan konsep berhitung dan konsep lain yang mendukungnya sesuai dengan tahapan perkembangan anak.

8 Suyanto, Slemet, Dasar-dasar Pendidikan Anak Usia Dini, (Yogyakarta: Hikayat Publishing, 2005).

${ }_{9}^{9}$ Suparno, Paul, Teori Perkembangan Kognitif Jean Piaget, (Yogyakarta: Kanisius, 2001). 


\section{B. Konsep Berhitung untuk Anak Usia Dini}

Secara psikologi matematika, konsep yang harus dikuasai anak sebelum anak belajar berhitung adalah pertama, konsep tentang himpunan. Konsep himpunan diperlukan untuk menentukan elemen-elemen dari himpunan atau kumpulan objek apa yang akan dihitung. Kedua, korespondensi satu-satu. Konsep korespondensi satu-satu menekankan masalah pe-label-an objek dengan angka atau elemen alphabet lain yang diucapkan. Jika konsep ini dikuasai, maka satu objek hanya akan mendapat satu label, dan sebaliknya, satu label hanya akan digunakan untuk satu objek. Anak tidak seharusnya mengatakan, "satu, dua, dua,", dimana elemen "dua" dipasangkan dengan dua objek, ataupun "satu, dua, tiga", untuk menghitung dua objek. Sehingga konsep korespondensi ini juga membutuhkan penguasaan sedikit konsep tentang himpunan, dimana dari kumpulan benda yang akan dihitung anak harus memisahkannya menjadi kelompok "mau dihitung" dan "sudah dihitung." Sehingga setiap objek tidak akan mengalami proses penghitungan lebih dari satu kali. Gelman dan Galistel secara khusus menyebut proses pemisahan ini dengan partitioning dan pemberian label pada setiap objek dengan angka atau alphabet lainnya disebut tagging. ${ }^{10}$

Konsep ketiga, bilangan kardinal. Bilangan kardinal diperlukan untuk memberikan pengertian kepada anak bahwa huruf atau angka terakhir yang disebutkan mempunyai makna khusus, yakni merupakan representasi himpunan secara keseluruhan sekaligus menunjukkan banyaknya objek atau jumlah elemen dalam himpunan tersebut. Tampak bahwa konsep ini tidak terlepas dari konsep korespondensi di atas, karena apabila anak memberikan label yang sama untuk dua objek ataupun memberikan dua label untuk satu objek (dengan menghitung ulang), maka angka terakhir yang diucapkan tidak lagi menunjukkan jumlah seluruh elemen dalam himpunan. Sehingga untuk membangun pengertian ini anak sebaik-

10 Marmasse, et.al., Numerical Mechanism and Childrens Concept of Numbers, (Cambridge: The Media Laboratory Massachussetts Institute of Technology, 2000). 
nya mempunyai pengalaman yang cukup dalam proses korespondensi satu-satu, dimana proses partitioning dan tagging berlangsung.

Sedangkan untuk membentuk pemahaman tentang himpunan, korespondensi satu-satu dan bilangan kardinal, anak harus sudah mempunyai modal mengurutkan, membandingkan dan mengumpulkan. Membandingkan dan mengurutkan pada dasarnya berbicara tentang perbedaan, sementara mengumpulkan berbicara tentang persamaan. Misalnya pada benda fisik, ketika anak membandingkan dua warna atau dua ukuran, maka anak harus mencari perbedaan warna atau ukurannya. Pada proses membandingkan, anak menganggap setiap objek berada pada tingkat nominal, sedangkan pada proses mengurutkan objek-obek berada pada tingkat ordinal. Oleh karena itu proses mengurutkan membutuhkan pengetahuan membandingkan, karena untuk dapat mengurutkan anak harus tahu apa yang menjadi pembeda. Dengan kata lain membandingkan merupakan konsep prasyarat dari mengurutkan.

Kemampuan untuk mengurutkan itu sendiri menjadi dasar untuk melatih anak mengurutkan bilangan, dari yang terkecil sampai yang lebih besar, sehingga menunjang pemahaman bahwa 2 lebih banyak dari 1, dan 3 lebih banyak dari 2. Kemampuan mengurutkan juga sangat mendukung proses pelabelan (tagging) dalam korespondensi satu-satu, karena label penghitungan harus tetap/ajeg dalam pengulangan urutannya. Misalnya, anak bisa saja menghitung 3 objek dengan menyatakan, "satu, tiga, empat" dan empat objek dengan "satu, tiga, empat, lima."

Tidak dimilikinya pemahaman dalam mengurutkan, membandingkan dan mengumpulkan pada anak yang sudah bisa membilang dan berhitung menurut Skemp ${ }^{11}$ akan berbahaya ketika pengetahuan itu dipindahkan ke bahasa tulisan. Untuk dapat mengurutkan, membandingkan, dan mengumpulkan, anak seyogianya sudah mempunyai dasar atas kriteria apa objek-objek diurutkan, dikumpulkan atau dibandingkan. Dengan demikian anak sudah mempunyai kemampuan untuk membeda-

${ }^{11}$ Skemp, R., The Psychology of Learning Mathematics. 
kan objek-objek untuk kemudian diklasifikasi atau dipisahkan berdasarkan kriteria-kriteria tertentu.

Dari gambaran di atas terlihat bahwa apabila mempertimbangkan aspek psikologi pembelajaran, membelajarkan berhitung pada anak tidaklah mudah, tidak hanya mengajarkan angka, bilangan, jumlah dan prosedur-prosedur penghitungan lainnya. Namun lebih daripada itu, membelajarkan berhitung melibatkan proses berpikir anak yang cukup komplek, yang apabila diabaikan

\section{Media Pembelajaran Berbasis Teknologi Informasi}

Media dalam pembelajaran matematika berfungsi antara lain untuk mengkonkritkan konsep yang abstrak, sehingga lebih mudah diterima anak. Terlebih pada anak usia dini dimana menurut Piaget taraf berpikirnya masih pada tahapan sensorimotor dan pra operasional. ${ }^{12}$ Oleh karena itu diperlukan media agar anak dapat berpikir mulai dari tahapan enaktif, ikonik hingga simbolik sebagaimana yang disampaikan oleh Bruner. Pada tingkatan enaktif, diperlukan media berwujud benda konkret seperti batu atau kelereng. Pada tingkatan enaktif, diperlukan media yang mensimulasikan benda konkret, seperti gambar batu atau gambar kelereng. Sementara pada tingkatan simbolik, batu dan kelereng dapat diganti dengan $x$ dan $y$.

Dengan teknologi informasi, manipulasi-manipulasi terhadap benda konkret dapat dilakukan dengan simulasi. Jika tahapan enaktif lebih ditekankan pada menghitung batu secara manual, dengan menggeser benda satu persatu, memisahkan mana yang sudah dihitung dan mana yang belum; maka proses ini juga dapat dilakukan melalui simulasi teknologi.

Penggunaan media berbasis tekologi informasi selain mengenalkan teknologi sejak dini kepada anak, juga memberikan beberapa dampak positif. Diantaranya adalah meningkatkan minat anak, anak akan tertarik dan tidak merasakan suasana belajar karena visualisasi dan audio yang

${ }^{12}$ Suparno, Paul, Teori Perkembangan Kognitif Jean Piaget. 
menarik. Dengan audio visual yang sesuai dengan kesukaannya, anak juga tidak merasa bosan untuk mengulangi. Selain itu, pendidik/orangtua juga dapat memasukkan unsur interaktif ke dalam media yang dibuat, sehingga melatih anak untuk berkomunikasi dan mengungkapkan gagasannya sendiri.

Kelebihan lain adalah bahwa teknologi informasi berkembang dari logika matematika, sehingga alur cerita dari media akan mengasah logika berpikir anak. Misalnya adalah ketika anak akan menjawab dengan benar akan muncul suara tepuk tangan atau tokoh yang memberikan selamat, ketika anak mengklik tombol EXIT akan keluar dari permainan, atau ketika anak berusaha untuk mengikuti instruksi lainnya; semuanya menunjukkan logika matematika khususnya implikasi yang berupa jika maka

Di samping bermanfaat untuk pengembangan kognitif, pengenalan teknologi informasi pada anak usia dini juga akan melatih motorik halus anak melalui gerakan mouse dan tekanan di keyboard. Anak akan terlatih untuk memperkirakan jarak geseran mouse, presisi letak kursor, serta kekuatan tekanan pada mouse dan keyboard.

Dibandingkan dengan media yang lain seperti media nyata atau visual yang terbuat dari kertas, media berbasis teknologi informasi lebih awet dan lebih mudah penyimpanannya. Para orangtua/ pendidik juga dapat saling berbagi media ini dengan mudah.

Meskipun mempunyai banyak kelebihan, penggunaan teknologi informasi pada anak-anak juga memberikan dampak negatif, diantaranya adalah radiasi monitor. Penggunaan yang berlebih dapat berakibat buruk pada mata anak-anak. Oleh karena itu kontrol dari orangtua mutlak diperlukan. Kontrol tersebut juga diperlukan untuk mengantisipasi anak dari kecanduan.

Secara khusus beberapa piranti teknologi informasi yang dapat digunakan untuk mengasah keterampilan berhitung pada anak usia dini adalah: 


\section{Kalkulator}

Alat ini merupakan salah satu media teknologi yang paling sederhana yang dapat digunakan. Seringkali dalam pembelajaran yang berkaitan dengan berhitung anak dilarang menggunakan kalkulator. Padahal kalkulator tidak selamanya berefek negatif terhadap anak. Pada anak usia dini, kalkulator dapat digunakan untuk menemukan berbagai fakta menarik tentang bilangan atau untuk menguji keterampilan berhitung mereka.

Pada tingkat usia yang lebih kecil (yang belum mampu berhitung), kalkulator berguna untuk pengenalan simbol bilangan. Anak juga dapat mengembangkan daya discovery-nya dengan melakukan eksperimen sederhana melalui bermain kalkulator. Bahkan fakta-fakta yang dianggap sangat biasa oleh orang dewasa akan menjadi luar biasa bagi anak jika mereka menemukan sendiri. Sebagai contoh, anak mungkin akan berteriak dengan bangga bahwa layar akan selalu berubah menjadi 0 ketika mereka menekan tombol $\mathrm{C}$ atau $\mathrm{AC}$.

Sementara bagi anak lebih besar yang sudah mengenal angka, kalkulator dapat digunakan untuk pengenalan operasi bilangan penjumlahan, pengurangan, perkalian dan pembagian. Sifat-sifat operasi bilangan seperti komutatif dan asosiatif dapat ditemukan dengan mudah melalui permainan kalkulator. Selain itu melalui kalkulator anak juga dapat mengenal bilangan besar. Dengan membiarkan anak menekan sembarang tombol angka di kalkulator, anak akan mengetahui bahwa bilangan bisa terdiri dari banyak digit.

\section{Microsoft Office PowerPoint}

Microsoft PowerPoint merupakan salah satu software yang paling banyak digunakan pendidik sebagai media pembalajaran di sekolah atau perguruan tinggi karena pengoperasiannya yang mudah dan kelengkapan menunya. Terlebih dengan adanya menu animasi, tampilan content slide dapat dibuat dengan lebih menarik. Karena mudah digunakan, MS PowerPoint dapat dimanfaatkan oleh para ibu rumah tangga untuk membuat pembelajaran yang fun bagi putra-putrinya. 
Pendidik, pengasuh atau orangtua dapat mendesain sendiri pembelajaran sesuai dengan tingkatan si anak. Untuk menunjang keterampilan berhitung, konsep mengurutkan, mengumpulkan, membilang, membandingkan, menjumlah dan mengurangi dapat dikombinasikan dengan gambar-gambar yang menarik. Berikut adalah contoh dari pemanfaatan MS PowerPoint untuk pembelajaran berhitung.

Slide di samping menunjukkan

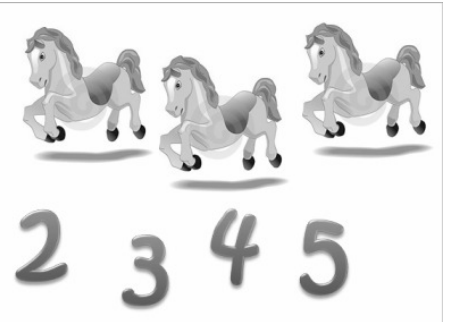
permasalahan yang harus diselesaikan anak, dimana anak diminta menentukan jumlah kuda yang ada. Untuk menjawabnya, anak tinggal menekan angka yang ada: 2, 3, 4 atau 5 . Masing-masing pilihan jawaban tersebut ter-link ke slide lain yang menunjukkan apakah jawaban yang dipilih benar atau salah.

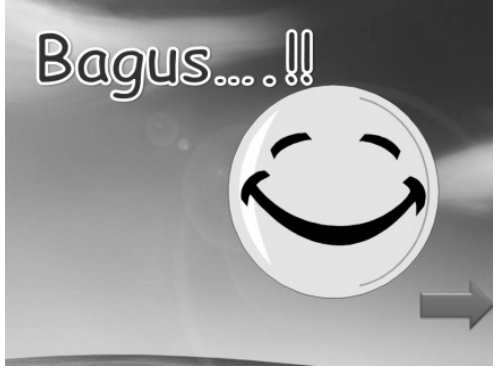

Apabila jawaban benar (dalam kasus ini adalah jika anak menekan angka 3) maka slide inilah yang akan muncul. Tanda panah di bawah kanan adalah yang harus ditekan anak untuk melanjutkan ke pertanyaan berikutnya.

Sedangkan apabila jawaban anak

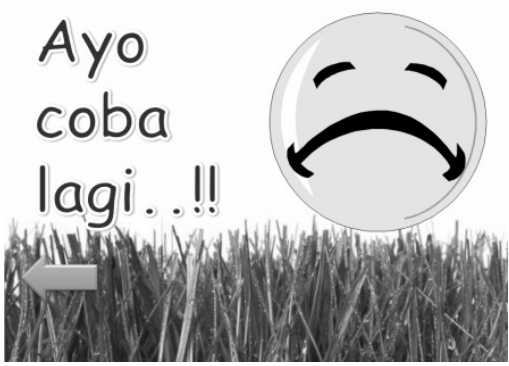
salah (yaitu jika menekan 2, 4, atau 5) maka slide inilah yang akan muncul. Kalimat "Ayo coba lagi" dapat diganti dengan rekaman suara ibu/pengasuh. Tanda panah ke kiri di pojok kanan bawah menunjukkan anak harus kembali ke soal untuk memperbaiki jawabannya. 
Para ibu/pendidik/pengasuh dapat mengembangkan contoh di atas sesuai dengan kebutuhan masing-masing anak. Agar lebih menarik, slide juga dapat disisipi lagu kesukaan anak.

\section{Internet}

Di internet, terdapat ribuan situs yang memuat pembelajaran berhitung. Namun tidak banyak yang menyediakan pembelajaran berhitung khusus untuk anak usia dini lengkap dengan konsep pendukungnya. Salah satu situs yang dapat digunakan untuk menguatkan kemampuan anak tentang konsep berhitung anak adalah http://www. countusin.com. Kelebihan situs ini antara lain pengunjung dipersilakan mendownload berbagai permainan sederhana untuk anak usia dini yang berbasis Macromedia Flash secara gratis. Diantara permainan yang disediakan untuk didownload adalah:

\section{a. Bowling-alley}

Permainan ini merupakan permainan bowling untuk anak dengan tampilan yang cukup menarik. Pada layar akan tertera $10-\ldots .=\ldots \ldots$ Angka 10 menunjukkan 10 bidak bowling, dan angka pengurangnya menunjukkan jumlah bidak yang akan jatuh terkena bola ketika dilempar. Hasil pengurangan merupakan banyaknya bidak yang masih berdiri.

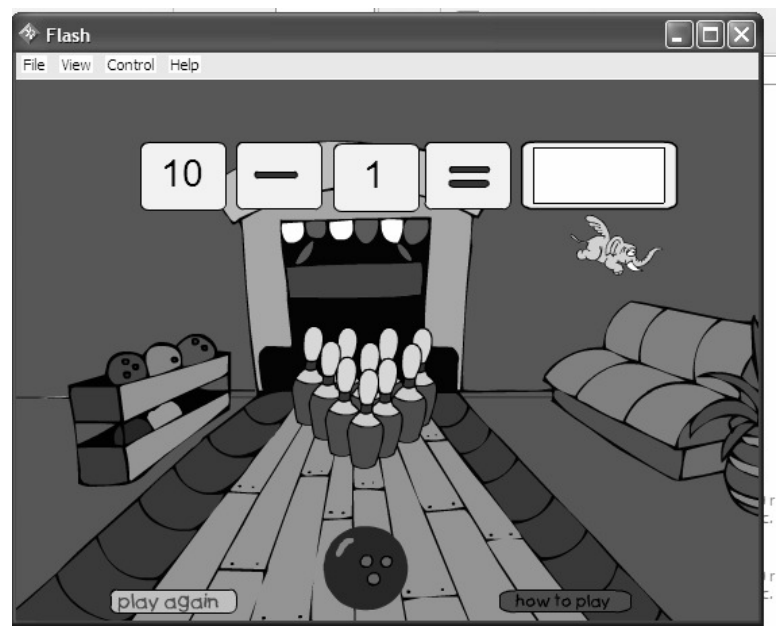


Anak akan diminta mengisi pengurangan tersebut sebelum menjalankan bola bowling. Jika anak salah dalam mengisi pengurangannya, maka bola tidak akan mau bergulir menuju bidak. Sementara jika anak mengisi pengurangannya dengan benar, maka bola akan bergulir dan anak dapat mencocokkan jawaban dengan menghitung banyaknya bidak yang masih tersisa. Pengurangan akan berlanjut sampai hasil pengurangan terakhir adalah 0, yang menunjukkan tidak ada lagi bidak yang akan tersisa. Permainan ini juga memberikan apresiasi jika anak berhasil, dan memberikan motivasi kepada anak apabila anak belum menjawab dengan benar.

Permainan ini akan bermanfaat secara optimal bagi anak yang sudah menguasai makna pengurangan, bilangan kardinal, dan membilang. Anak yang belum memahami makna itu pengurangan atau belum dapat membilangkemungkinan akan mengisi pengurangan dengan acak, sehingga tidak memberikan hasil yang optimal.

Secara khusus kompetensi yang diasah melalui permainan ini adalah:

1) Motorik Halus. Dengan menggerakkan mouse untuk menjalankan bola dan mengisi kotak jawaban, anak akan berlatih mengontrol mouse secara pelan dan halus.

2) Konsep Pengurangan, yaitu mengambil sebagian atau seluruh objek yang sudah ada, sehingga jumlahnya menjadi lebih sedikit atau habis sama sekali. Bidak yang berjumlah 10 sangat membantu anak untuk menanamkan konsep bahwa pengurangan merupakan lawan dari penjumlahan. Sebagai contoh, jika anak sudah memahami bahwa $5+5=10$, anak dapat dibimbing untuk memahami bahwa 10-5=5.

3) Bilangan Kardinal dan Membilang. Ketika anak mencocokkan jawaban dengan menghitung sisa badak bowling, anak akan semakin terlatih

4) Korespondensi Satu-satu. Badak bowling yang disusun dengan tidak linear akan melatih anak teliti dalam hal korespondensi satusatu, bidak yang sudah dihitung tidak seharusnya dihitung ulang.

5) Hubungan Bilangan 10 dengan Bilangan di Bawahnya. Bidak bowling yang berjumlah 10 dan selanjutnya dikurangi bilangan tertentu, jika dilakukan berulang-ulang akan membuat anak 
paham beberapa hubungan bilangan 10 dan bilangan di bawahnya. Sebagai contoh, 10-1=9, 10-2=8, 10-3=7, dan seterusnya sampai $10-9=1$. Ketika bilangan pengurang bertambah satu, maka hasil pengurangannya berkurang satu. Hubungan lain yang bisa ditanamkan adalah pasangan 1-9, 2-8, 3-7, 4-6, dan 5-5 yang jika dijumlahkan menghasilkan bilangan 10 .

6) Konsep Bilangan Nol. Bilangan nol akan muncul jika setiap bilangan dikurangkan dengan dirinya sendiri. Dengan visualisasi bidak bowling, anak dapat memahami bahwa nol berarti tidak ada objek (bidak) sama sekali.

\section{b. Feather-counter}

Pada permainan ini anak diminta mencocokkan jumlah objek di dalam bulu merak yang terlepas dengan angka yang ada di dalam bulu yang menempel. Bulu tidak dapat menempel ke merak jika anak salah dalam menjawab. Sebaliknya, jika seluruh jawaban benar, maka akan ada dua tokoh kartun yang memberikan apresiasi kepada anak.

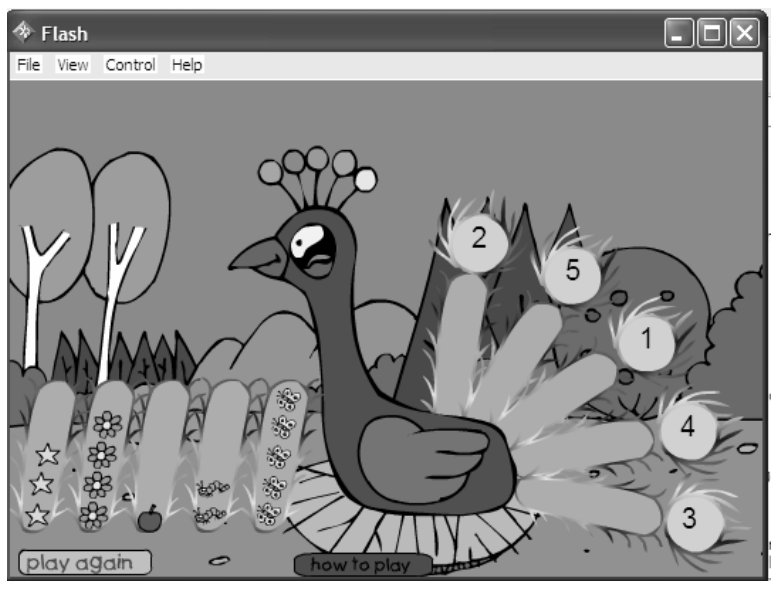

Secara khusus kompetensi yang diasah melalui permainan ini adalah:

1) Bilangan Kardinal dan Membilang. Untuk dapat mengetahui jumlah motif pada masing-masing bulu yang terlepas, anak harus menghitung terlebih dahulu. 
2) Korespondensi Satu-satu. Dengan memasangkan bulu, anak akanmelihat bulu bernomor yang msih kosong. Bulu bernomor yang sudah terisi motif seharusnya tidak lagi diisi oleh motif yang lain.

3) Motorik Halus. Dibutuhkan gerakan mouse yang sangat halus pada permainan ini untuk menaruh bulu yang telepas ke dalam bulu bernomor di tubuh merak.

\section{c. Frog-jump}

Inti dari permainan ini adalah mengurutkan bilangan dari 10 sampai 25. Seekor katak akan berdiri di tepi sungai, hendak menyeberang dengan melompati daun teratai. Anak harus memilih daun teratai yang akan diinjak katak dengan menentukan urutan angkanya. Jika anak salah memilih daun, maka katak akan tenggelam. Sebaliknya, jika anak berhasil menyeberangkan katak maka akanmuncul dua tokoh kartun yang memberikan apresiasi. Agar permainan ini dapat berfungsi optimal, minimal anak harus sudah menguasai bilangan 1 sampai 9

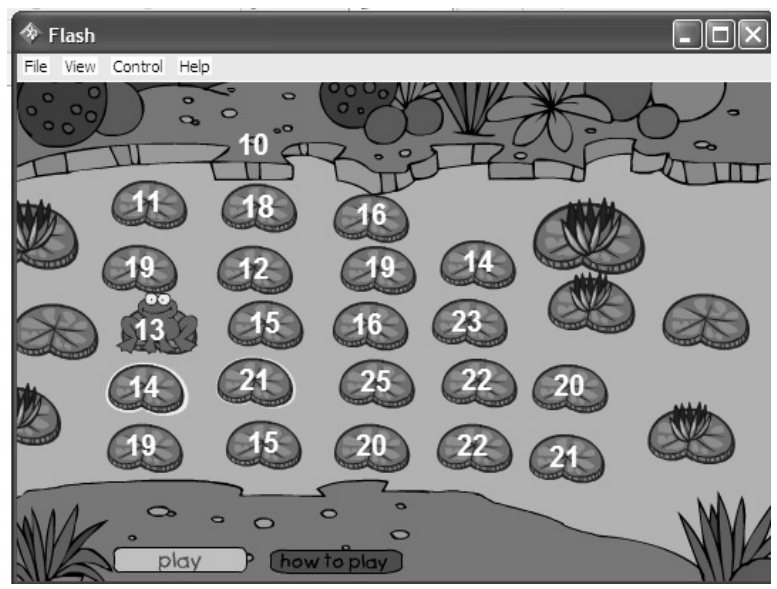

Secara khusus kompetensi yang diasah melalui permainan ini adalah:

1) Mengurutkan. Tujuan utama dari permainan ini adalah membantu anak menghafalkan urutan bilangan 11 sampai 20 . 
2) Membandingkan dan Memisahkan. Dari satu deret bilangan, hanya ada satu bilangan yang merupakan urutan dari bilangan sebelumnya. Dengan memilih bilangan-bilangan dalam deret tersebut, anak akan dilatih membandingkan hubungan antar bilangan. Sebagai contoh, jika bilangan sebelumnya adalah 13, sementara deret dilangan berikutnya adalah 12, 25, 22, 14 dan 30, maka anak dapat menentukan 12 bukan urutan berikutnya karena 12 lebih kecil daripada 13, 21, 25, 22 dan 30 juga bukan urutan karena bilangan tersebut berada jauh di atas 13 .

\section{d. Memory}

Konsep dari permainan ini adalah mencari nilai waktu yang sama antara jam digital dan jam analog. Namun anak tidak perlu menguasai cara membaca jam dengan detail untuk dapat memainkan permainan ini, karena semua jam ditunjukkan dalam bilangan bulat. Tidak ada jarum yang menunjukkan menit 15, 30, 20, dan sebagainya. Semua waktu ditunjukkan dalam menit 00. Sehingga dapat dikatakan anak hanya akan mencocokkan bilangan bulat yang ditunjukkan jarum dalam jam analog dengan bilangan yang muncul dalam jam digital.

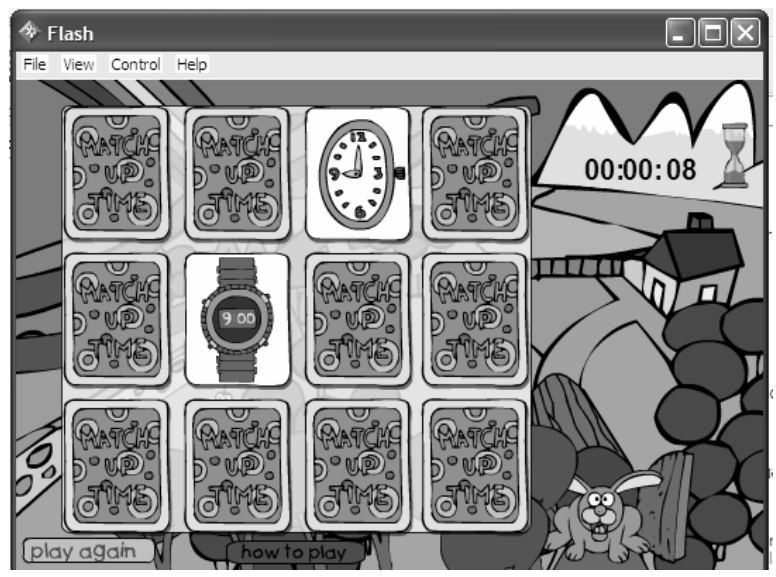

Beberapa keterampilan yang diasah dalam permainan ini adalah;

1) Konsentrasi dan Daya Ingat. Permainan ini sangat menekankan pada bagaimana anak belajar konsentrasi dan mengingat 
dengan baik. Adanya timer memacu anak untuk dapat melakukan kedua hal tersebut dengan cepat.

2) Konsep Waktu. Dalam kehidupan sehari-hari, penggunaan jam analog dan jam digital merupakan hal yang biasa. Melalui permainan ini, anak belajar untuk mengenal konsep waktu, terutama bahwa angka 12 adalah angka tertinggi yang digunakan untuk menyatakan waktu. Selain itu, melalui penyajian dua jenis jam, anak akan belajar cara membaca waktu melalui jam digital dan jam analog.

3) Bilangan Bulat. Dengan memperhatikan angka yang ditunjukkan jam digital atau ditunjukkan jarum pada jam analog, anak akan semakin mengingat bilangan bulat dan urutannya.

\section{e. Flying-girl}

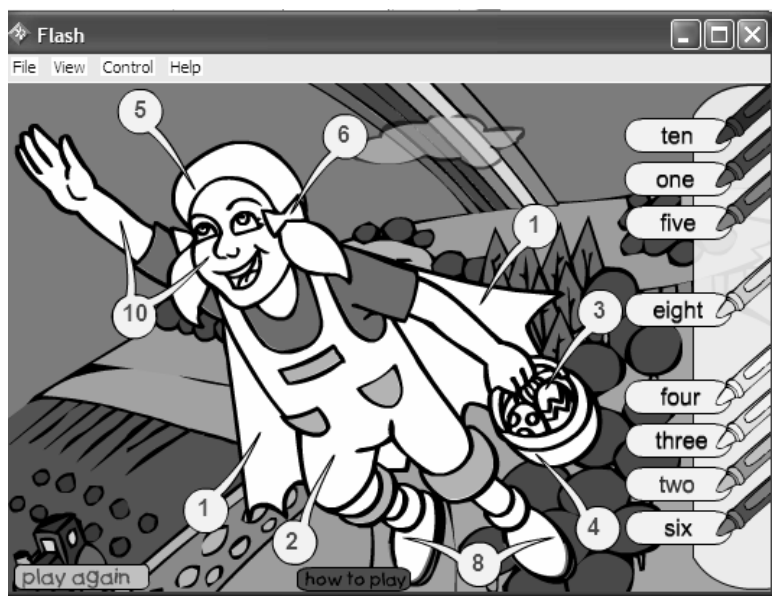

Anak-anak dapat dipastikan akan menyukai permainan ini karena selain mudah dioperasikan permainan ini juga mengasah kreativitas anak. Permainan ini terdiri dari dua bagian utama. Bagian pertama adalah gambar seorang superhero perempuan yang terbang dilengkapi dengan angkadi hampir seluruh bagian tubuhnya. Gambar gadis ini masih putih, tanpa warna. Bagian kedua memuat pensil warna beserta angka dalam bahasa Inggris yang ditulis dengan huruf. Tugas anak adalah memasukkan 
pensil warna sesuai dengan nomor yang tertera di tubuh perempuan, sehingga gambar superhero tersebut akan menjadi berwana-warni.

Melalui permainan ini, keterampilan anak yang bisa diasah adalah:

1) Pengenalan Warna. Terdapat banyak kombinasi warna yang disediakan di sini. Meskipun gambarnya selalu sama, namun tiap kali anak memulai permainan mereka akan menemukan kombinasi warna yang berbeda. Kreativitas anak akan semakin terlatih melalui kombinasi-kombinasi tersebut

2) Pengenalan Angka dalam Bahasa Inggris. Dengan memperhatikan nomor pensil warna yang ditulis dalam bahasa Inggris, akan menguatkan memori anak tentang tulisan angka dalam bahasa tersebut. Dengan bimbingan orangtua atau pengasuh, anak dapat dipandu untuk mengucapkan tulisan tersebut dengan benar.

3) Menjodohkan. Dalam permainan ini gambar anggota tubuh superhero tidak akan berwarna apabila pemain (anak) memasukkan pensil warna yang tidak sesuai antara tulisan dan simbol bilangannya. Menjodohkan ini sekaligus bisa menjadi kunci jawaban apabila anak tidak tahu penulisan salah satu bilangan dalam bahasa Inggris. Jika warna dapat dimasukkan berarti jawabannya benar, dan jika warna tidak dapat dimasukkan berarti jawabannya salah.

\section{f. Sorting}

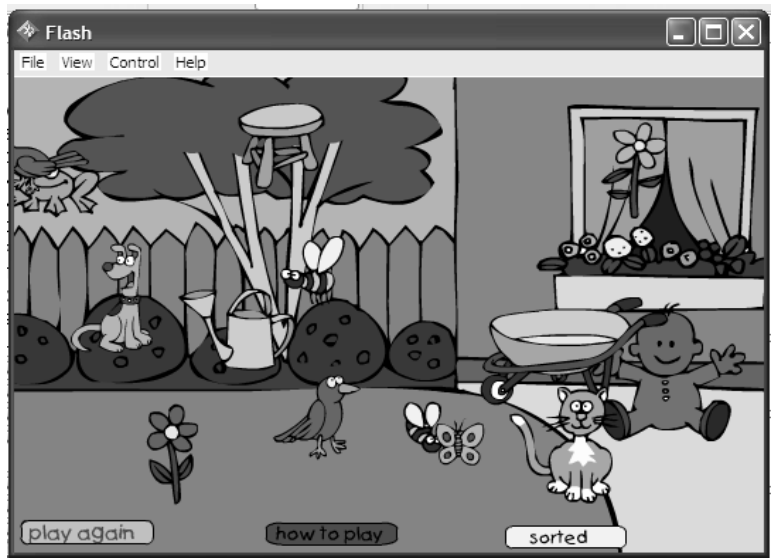

SAWWA - Volume 7, Nomor 2, April 2012 
Permainan ini merupakan salah satu permainan konsep dsar berhitung yang sangat tepat untuk anak usia dini. Di permainana ini, anak akan diminta untuk mengurutkan benda-benda mulai dari yang terkecil hingga terbesar atau tertinggi. Benda-benda yang ada merupakan benda yang sangat kontekstual, sering dijumpai di lingkungan sekitar.

\section{g. Halves}

Tujuan dari permainan ini adalah menemukan pasangan benda dengan setting pantai. Layout game ini terdiri dari dua bagian, bagian kanan berisi pemandangan dipantau dengan berbagai benda saling tergeletak, sementara di bagian kiri adalah pasangan masing-masing benda yang tergeletak tersebut. Anak diminta menarik benda di sebelah kiri untuk dipasangkan dengan benda di apntai di sebelah kanan. Yang menarik dari game ini adalah ketika anak sudah berhasil memasangkan, benda tersebut akan bergerak dengan lucu.

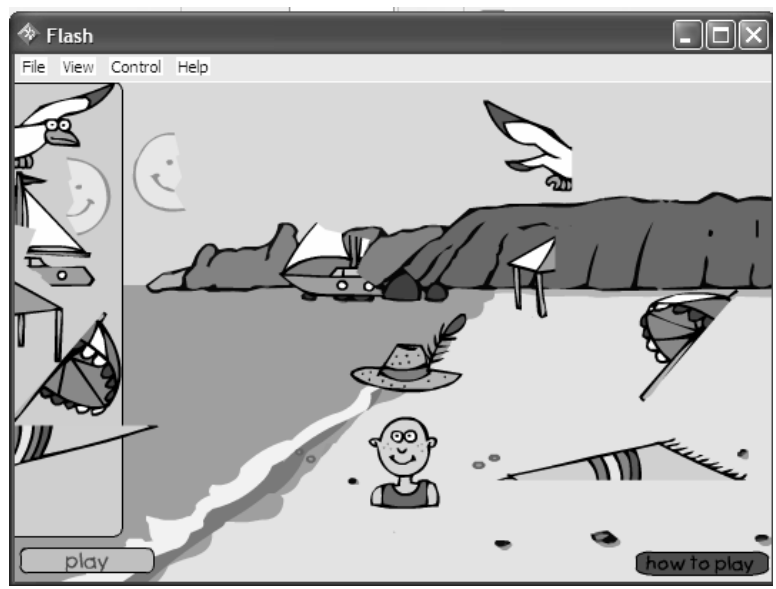

Yang diharapkan dikuasai anak dalam permainan ini adalah:

1) Ketelitian. Benda-benda yang ada di lantai tidak tertaruh dengan rapi, namun acak. Sehingga untuk menemukannya, anak harus melihat dengan teliti. 
2) Berpikir Terbalik. Berbagai benda yang harus dipasangkan anak terbagi dua, yaitu kanan dan kiri. Bagian benda yang sebelah kanan merupakan cermin dari bagian kirinya. Demikian juga sebaliknya. Sehingga dengan mencari atau mengamati pasangannya, anak juga diajak berpikir terbalik dengan melihat invers-nya.

\section{h. Volume}

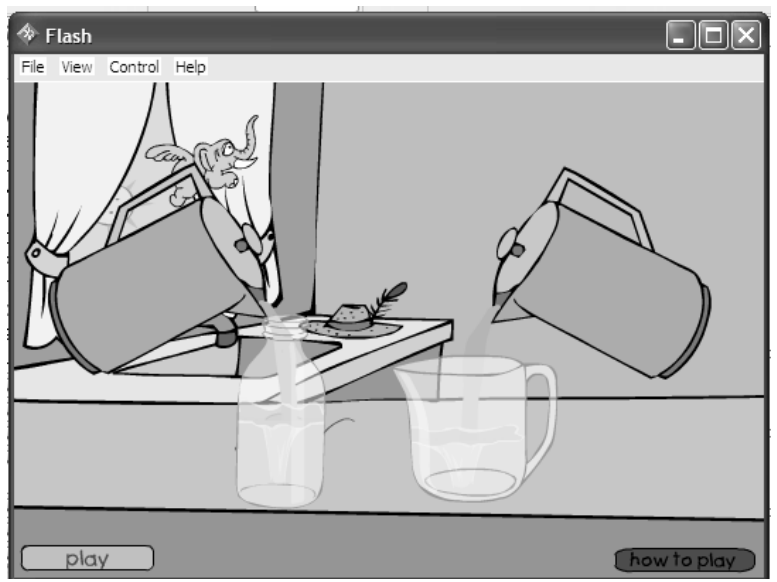

Permainan ini merupakan permainan yang fokus pada tujuan penguasaan anak dalam kompetensi membandingkan. Terdapat dua teko yang masing-masing akan menuang air ke gelas atau botol. Anak diminta menentukan tempat air manakah yang mempuyai volum lebih banyak? Meskipun terlihat sepele, namun pada kenyataannnya anak tidak selalu dapat menentukan gelas mana yang mempunyai vlum lebih banyak, terutama jika gelas yang besar ketinggian airnya rendah, sedangkan pada gelas/botol yang kecil airnya cukup tinggi.

\section{h. Height}

Dalam permainan ini, terdapat enam atlet olahraga. Anak diminta mengurutkan tinggi badan atlet-atlet tersebut, mulai dari yang tertinggi sampai terendah. Di layar terdapat timer untuk mengukur waktu yang dibutuhkan anak untuk mengurutkan tinggi badan keenam atlet tersebut. 
Secara khusus kompetensi yang bisa dikembangkan melalui permainan ini adalah:

1) Membandingkan. Sebelum anak menentukan siapa yang tertinggi, proses pertama yang dilalui anak adalah membandingkan apakah atlet yang satu lebih tinggi daripada atlet yang lain. Proses membandingkan ini membutuhkan ketelitian dari anak karena beberapa atlet mempunyai tinggi yang tidak jauh berbeda.

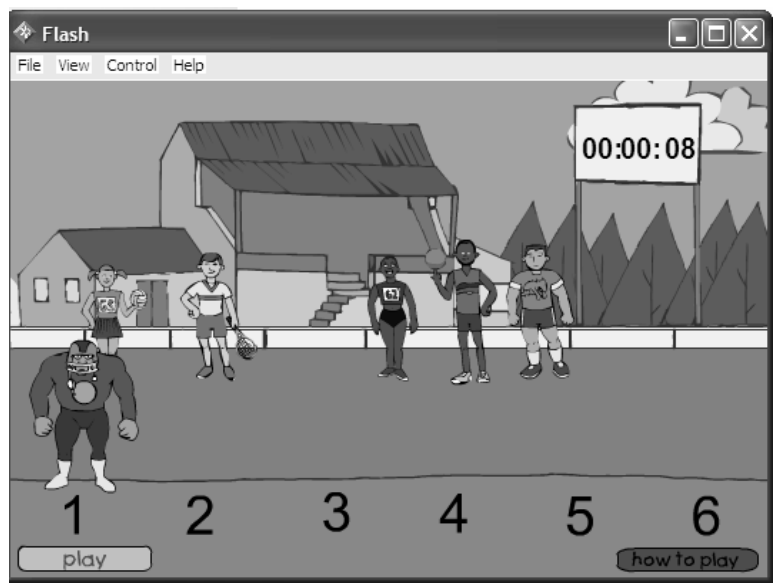

2) Mengurutkan. Setelah anak berhasil melakukan perbandingan, proses berikutnya yang dilakukan anak adalah mengurutkan dari yang tertinggi sampai yang terendah.

3) Keterampilan motorik halus. Pada saat mengurutkan, ketika seorang anak sebagai pemain memutuskan salah satu atlet adalah yang tertinggi, pemain harus "membawa" atrlet tersebut ke nomor sesuai urutannya. Pada proses inilah anak dilatih keterampilan halus karena anak harus menjaga agar tekanan pada mouse tidak lepas sekaligus menempatkannya di posisi yang tepat.

Contoh di atas hanya beberapa diantara sekian banyak yang ditawarkan di htttp://www.countusin.com. Pun masih banyak situs lain yang bisa digunakan. Namun yang terpenting adalah orangtua atau 
pendidik mengetahui tahapan perkembangan yang sedang dialami anak, sehingga dapat mendesain atau memilih media yang tepat untuk anak.

\section{Kesimpulan}

Dalam membelajarkan materi berhitung pada anak usia dini, hendaknya orangtua/pendidik tidak terlalu memaksakan kemampuan anak. Yang lebih penting untuk diperhatikan adalah apakah anak sudah menguasai konsep dasarnya atau belum. Untuk itu orangtua/pendidik dapat menggunakan media berbasis teknologi informasi yang sekarang ini sangat mudah diperoleh. Diantaranya adalah kalkulator, Microsoft PowerPoint, dan internet. Orangtua/ pendidik juga dapat menggunakan mobile teknologi, seperti handphone atau tablet. Masing-masing mempunyai kelemahan dan kelebihan, orangtua/pendidik dapat memilih sesuai kebutuhan anak.[]

\section{Daftar Pustaka} Amandemen UUD 1945

UU No. 23 Tahun 2002 Perlindungan Anak

UU No. 20 Tahun 2003 tentang Sistem Pendidikan Nasional

http://www.countusin.com. diakses tanggal 5 Desember 2011.

Marmasse et.al., Numerical Mechanism and Childrens Concept of Numbers. Cambridge: The Media Laboratory Massachussetts Institute of Technology, 2000.

New Foundations, Jerome Bruner's Educational Theory, (2001), http://newfoundations.com/gallery/bruner.html (1 Juni 2008)

Skemp, R., The Psychology of Learning Mathematics, Harmondsworth, Middlesex, England: Penguin Books Ltd., 1971.

Sujiono \& Sujiono, Menu Pembelajaran Anak Usia Dini. Jakarta: Yayasan Citra Pendidikan Indonesia, 2005. 
Suparno, Paul, Teori Perkembangan Kognitif Jean Piaget, Yogyakarta: Kanisius, 2001.

Suyanto, Slemet, Dasar-dasar Pendidikan Anak Usia Dini, Yogyakarta: Hikayat Publishing, 2005. 